\title{
Romanda postmodern ögeler
}

\section{Emre Bekir GÜVEN1}

APA: Güven, E. B. (2020). Romanda postmodern ögeler. RumeliDE Dil ve Edebiyat Araştırmaları Dergisi, (19), 378-386. DOI: 10.29000/rumelide.752364.

\section{$\ddot{\mathbf{O z}} \mathbf{z}$}

Felsefi ve sosyolojik açıdan Postmodernizm’in en çok hangi alana/disipline yansıdığı sorusuna bir cevap bulmak aslında güç değildir. "Postmodern müzik” veya "postmodern sinema” gibi kavramlar "postmodern edebiyat" kadar sık duyulmamaktadır. Ayrıca Lyotard'ın disiplinlerarası ayrımı reddetmesi ve Postmodernite ile birlikte "interdisipliner" ile "transdisipliner" gibi kavramların önem kazanması gibi gerçekler göz önünde bulundurulduğunda Postmodernizm’in edebiyat disiplini ile ilişkisini vurgulamak bu açıdan "mantık dışı"dır. Buna rağmen, "Postmodernizm” ve "roman"ı iki farklı disipline ait kavramlar olarak görsek bile, birbirlerine olan bağları oldukça sıkıdır. Edebiyatın anlatı dünyasının belki de en büyük ürünü olan romanın Postmodernizm'den aldıkları romanı farklı bir boyuta taşımıştır. Postmodern roman göze ilk bakışta bir dönem gibi görünse de bir türdür. Modernite sonrası dönemde yazılmış her romanın postmodern roman olduğunu iddia edemeyiz. Postmodern romanı postmodern roman yapan metinlerarasılık, üstkurmaca gibi öğeler modernite sonrası yazılmış her romanda mevcut değildir. Bunların dışında (bazıları alt tür) montaj, kolaj, pastiş, parodi, ironi gibi tekniklerde de aynı durum söz konusudur. Yazarın dehasını ve okurun aptallığını ön plana süren postmodernist romancı/roman yazarı sayısı, geri kalan sayısız roman yazarının yanında sınırlıdır. Dünyada Italo Calvino, Umberto Eco, Paul Auster, Patrick Süskind; Türk edebiyatından Oğuz Atay, Orhan Pamuk gibi sınırlı sayıda romancılar postmodern roman örnekleri sunmaktadır. Bu çalışmada, okuma süreci "kaliteli" okur için oldukça yorucu ama bir o kadar zevkli olan, "aptal" okura ancak sınırlı bilgi sunan postmodern romanlar tartışılmaktadır. Postmodern romanların, postmodern öğelerinin neler oldukları irdelenmekte ve okurun bu öğelerden biri haline nasıl dönüştüğü sorgulanmaktadır.

Anahtar kelimeler: Postmodern, roman, ögeler, üstkurmaca, metinlerarasılık

\section{Postmodern elements in the novel}

\begin{abstract}
Postmodernity, whose connection with modernity has not yet been fully revealed, has carried itself beyond being a philosophical and sociological value system. It is possible to see postmodernism in literature, cinema, music, architecture and plastic arts today. Postmodernism, which can conceptually date back to 1870 s through the painter Chapman, in fact, made its presence felt in the 1960s. The reflection of the concept in literature, which has been discussed by some platforms today about whether it is a period or a current, is quite interesting. We see a trend in the literature that pushes aside the traditions and judgments that have been created up to that day and does not care about this situation. From a philosophical and sociological point of view, it is actually not difficult to find an answer to the question of which field/discipline Postmodernism is reflected in the most.
\end{abstract}

1 Dr. Öğrencisi, Atatürk Üniversitesi, Sosyal Bilimler Enstitüsü, Alman Dili ve Edebiyatı ABD (Erzurum, Türkiye), emrebekirguven@gmail.com, ORCID ID: oooo-0002-1789-1730 [Makale kaylt tarihi: 15.05.2020-kabul tarihi: 20.06.2020; DOI: 10.29000/rumelide.752364] 


\begin{abstract}
Concepts such as "postmodern music" or "postmodern cinema" are not heard as often as "postmodern literature". In addition, when facts such as Lyotard's refusal of interdisciplinary distinction and concepts such as "interdisciplinary" and "transdisciplinary" gaining importance together with Postmodernity are concerned, it is "irrational" in this respect to emphasize the relationship of postmodernism with the discipline of literature. Still, even though we see "postmodernism" and "novel" as concepts belonging to two different disciplines, their connection to each other is quite tight. The things that the novel, perhaps the biggest product of the narrative world of literature, took from Postmodernism, carried the novel to a different dimension. Although the postmodern novel may seem like a period at first glance, it is a genre. We cannot claim that every novel written in the postmodern period is a postmodern novel. Elements such as intertextuality and metafiction that give postmodern novels their unique characteristics are not present in every novel written after Modernity. Apart from these, the same situation is valid in techniques such as montage, collage, pastiche, parody, irony (some of which are subgenres). The number of postmodernist novelists who put forward the genius of the writer and the stupidity of the reader is limited compared to the countless remaining novelists. Novelists, who are not limited to names such as Italo Calvino, Umberto Eco, Paul Auster, Patrick Süskind in the world, and Oğuz Atay, Orhan Pamuk in Turkish literature, but are still limited, offer postmodern novels. In this study, postmodern novels, whose reading process is rather exhausting but equally pleasurable for "quality" readers, and which offer only limited information to "stupid" readers, are discussed. The study examines what the postmodern elements of postmodern novels are and how the reader turns into one of these elements.
\end{abstract}

Keywords: Postmodern, novel, elements, metafiction, intertextuality

\title{
Giriş
}

Postmodernizmi sadece tanımlamak dahi başlı başına kapsamlı bir araştırma konusudur. "Post" ön eki üzerine dahi sayısız tartışmaya rastlamak mümkündür. Fakat bütün bunları bir kenara bırakarak bu işin asıl kuramcısına başvurmak gerekir. Fransız filozof Jean-François Lyotard 1979 yılında yayımladığı Postmodern Durum (La condition postmoderne) adlı çalışmasında postmodernizmi şöyle tanımlamıştır: "Aşırı basitleştirilmiş bir ifadeyle diyebiliriz ki, 'postmodern' sayzlan tutum, üstanlatılara karşı inançsızlıktır.” (Lyotard, 2014: 8). Lyotard'ın bu üst-anlatılar (meta-anlatılar) ile kastettiklerini çeşitli doktrinlere, öğretilere, akımlara, hareketlere yormak mümkündür. Aydınlanma, idealizm, tarihselcilik, Marksizm vs. gibi birçok harekete yorumlanabilir; fakat Lyotard'ın burada sadece belirli doktrinlere karşı durduğu sonucunu çıkarmamak gerekir. Yorumlanarak ortaya koyulursa, postmodernizmin anarşist, kuşkucu, şizofren tavrının tüm üst-anlatılara karşı geçerli olduğu söylenebilir. Yani herhangi bir anlatıya, bu romantizm dahi olsa, postmodernistler kuşkuyla yaklaşmaktadır. Dolayısıyla Lyotard'ın kastettiği belirli anlatılara karşı durma değil, var olan tüm anlatılara karşı kuşkuyla yaklaşmadır. Bir tutum, tavır söz konusudur.

"Postmodern" sözcüğünün ilk defa, 1870 yllı civarında İngiliz ressam John Watkins Chapman tarafından kullanıldığı söylense (Best \& Kellner, 2016: 22) de bunun bugünkü anlamıyla kullanıldığını düşünmek mümkün değildir. Evet, "postmodern" sözcüğünün sadece Chapman tarafından değil, asıl tartışmaların başladığı döneme kadar kullanıldığını tahmin edebiliriz. Fakat bunlara postmodernizmin bugünkü anlamını atfetmek mantık dışı bir değerlendirme olur. Bu tür kullanımlar daha çok halk arasında "Yeni Çă̆" olarak bilinen Modern Dönem'in bittiğini ve Modern Dönem sonrası bir dönemin başladığını ifade etmek için kullanılmıştır. Zira Modern Dönem (Erken Modernite) 1475-1875 arasına 
tarihlenir (Best \& Kellner, 2016: 22.). Dolayısıyla, asıl tartışmalarının başladı̆̆g 196o'lı yıllara kadar kavramsal bir postmodernizmden bahsedemeyiz. Lyotard'ın yanı sira Michel Foucault, Jacques Derrida gibi isimler öncülüğünde bu dönemde başlayan ve 70’li yıllarda ağırlık kazanan tartışmalara daha sonra Baudrillard, Deleuze, Vattimo, Bauman gibi başka isimler de dahil olmuştur.

Postmodernizmin bir kavrama oturtulmasının ardından bu yeni tutumun disiplinlere yansıması gecikmemiştir. Mimari, resim, müzik, dans gibi edebiyata yansımıştır. Felsefenin edebiyat ile olan bağı düşünüldüğünde bu yansımanın kaçınılmaz olduğunu söyleyebiliriz. Roland Barthes, Julia Kristeva ve Wolfgang Iser üzerinden kuramsallaştırıldığı dillendirilen (Hassan, 2019: 310) postmodern edebiyat en çok romanda kendisine yer bulmuştur. Romanın kısıtlamalara gelmeyen, özgürlüğü seven yapısı postmodern felsefeyle oldukça uyumludur.

\section{Postmodern roman}

Romanın kısıtlanmayı sevmediği, romanı kısıtlamanın ve belirli bir çerçeve oturtmanın onun "hayat damarlarındaki kanın emmek" (Stevick, 2017: 7) demek olduğu ifade edilir. Gerçekten de romanı güçlü kılan onun özgür yapısıdır. Her türlü şeyi anlatabilen istediği zaman istediği noktaya yönelebilen roman, bu sayede anlatı dünyasının tartışmasız lideridir. 20. yüzyılın teknoloji tehdidine karşı ayakta durabilmiştir. Bugün hala kitabevlerinin başköşelerinde romanları görürüz. 1970’li yıllardan günümüze dalgalar haline gelen ve adeta romana kafa tutan nitelikte olan filmlere rağmen roman bugün ayaktadır.

Romanın klasik Hugo, Goethe, Dostoyevski anlatılarındaki şekliyle devam etmesi onu 20. yüzyllın son çeyreğinde hangi noktada konumlandırırdı, tahmin etmek güçtür. Elbette bu isimlerin yapitları hala kütüphanelerin kült metinlerini oluşturmaktadır. Bu gerçeğe karşı durmak mantıklı bir tez olmaz. Fakat 20. ve 21. yüzyılların kesiştikleri noktada başta sinema olmak üzere diğer sanat dalları ve teknolojileri karşısında yara almadan nasıl varlıklarını sürdürecekleri ayrı bir konudur. Duru anlatı metinleri olarak, okura huzur veren, onu huzurla uyutan metinler olarak Titanic (1997), Yüzüklerin Efendisi (2001-2003), Harry Potter (2001-2011), Avatar (2009) gibi filmlerin karşısında ne yapacaklarını tahmin etmek güçtür. Evet, bu filmler içerisinde de romandan uyarlama olanlar vardır. Fakat bu filmlerin, kaynak metinleri solladığı, farklı bir boyuta taşıdığı da bir gerçektir. Dolayısıyla romana taze bir kan gerekliydi. Ancak bu sayede varlığını sürdürebilirdi. Klasik romanlar da dahil olmak üzere kabul görmüş anlatı anlayışını kıracak ve ortaya yepyeni bir şey koyacak olan romanlar gerekliydi. Postmodern roman bunu sağlamıştır.

Edebiyat bilimci Yıldız Ecevit içinde yaşadığımız dünyayı Üç Silahşörler'den çok Ulysses'e benzetir (Ecevit, 2016, 170). 20. yüzyll dünyası akıp giden anlatılardan ziyade kaosu gözler önüne seren metinler gerektirir. İki tane dünya savaşı gören, bölgesel krizlerin bitmediği, gerçeklik algısının ters yüz olduğu, insanın birey olmayı gerçekleştiremediği bu yeni insanın klasik anlatı metinlerini anlaması, bu metinlerdeki karakterlere karşı empati kurması olanaksızdır. Yeni dünyada birey olamamış kişiye Kafka'nın, Joyce'un, Musil’in metinleri gereklidir. Neden-sonuç ilişkisinin yok edildiği bir Kafka metnidir yeni dünya. Yeni dünya için Josef K.'nin önce tutuklanması ve bu durumu anlamsız bir şekilde önce boş vermesi, sonra üzerine düşmesi, sonra yine boş vermesi ve en sonunda hançerlenmesi durumu söz konusudur. Eskiden olduğu gibi önce yokluk çekip, sonra cinayet işleyen ve bunun açığa çıkmaması için ter döken bir neden-sonuç ilişki söz konusu değildir. İnandı ̆̆ değerlerin boş ve faydasız olduğunu yaşayıp gören bu yeni insan için dünya farklı bir yerdir. 
Freud'un psikanalizi, Heisenberg'in belirsizliği, Einstein'ın izafiyeti, Planck'ın kuantumu eski ile yeni insanı ayırır. Yeni insan gerçeğe karşı kuşkuludur, kurmaca bir gerçeklik ile gerçek bir kurmaca arasında gidip gelir. Her şey hayali bir düzlemde oynanan bir oyundan ibarettir. Kişi birey olmayı başaramamıştır; hatta kimliksizdir. Bir olgu değil, birçok olgu vardır. Her şey birden fazladır. Bir şeylerin başka bir şeylerle sürekli olarak ilişkisi vardır. Kopyalamak, çalmak bir sorun değildir. Katı kırılganlıklar, parçalanmalar, ayrılıklar, zıtlıklar söz konusudur. Bütün bu olgular romanda yer bulur. Postmodern roman üstkurmaca ve metinlerarasılık düzleminde referans, pastiş, parodi, ironi, kolaj teknikleriyle bu söz konusu olguları ele alır.

Postmodern roman Ecevit'in ifadesiyle "mimari bir kurgu" (Ecevit, 2016: 165) ortaya koyar. Artık roman yazmak yeterli değildir, romanı kurmak gerekir (Ecevit, 2016: 165). Klasik metinlerin ilgi çekici, zamandan ve mekandan bağımsız olarak kapsayıcı oldukları sürece okunduklarını, değer gördüklerini biliyoruz. Postmodern romanda ise ortaya yepyeni bir ürün koyma, adeta "yaratma" edimi söz konusudur. Postmodernist romancı bunları yaptığı sürece zaten okunacağını bilir. Ayrıca böyle bir kaygısı da yoktur. Beğenilmiş veya beğenilmemiş, şu mesajı vermiş veya vermemiş, gerçekçidir veya fantastiktir gibi kaygılar asla söz konusu değildir. Postmodernizmin önemli ismi Mısır-Amerikalı Ihab Hassan bu söz konusu anlayışı, herhangi bir sisteme oturtmayı "kötü bir şiir" (Hassan, 2019: 312) olarak tanımlar. Dolayısıyla postmodern roman olabildiğince özgürdür ve bir kaygısı yoktur. Bu özgürlük ortamında yaratıcılığını ve yenilikçiliğini sonuna kadar konuşturur.

Postmodern roman yorucu olduğu kadar zevklidir. Alışılmış, klasik ölçütleri yıkan yapısıyla devrimcidir. İnovatif tavrıyla yenilikçidir. Romancının dehasının göstergesidir. Romancı kadar okurun da kafa yormasını bekler. "Bilgili" okur ister ve "aptal" okura kendisini kapatır. Belirli bir bilgi seviyesini şart koşar. Kısacası uyku halinde okunacak eserler değillerdir. Postmodern romanın eleştirilme nedenini anlaşılmamasına dayandırabiliriz. Bunun bir istatistiğe dayandıramasak da bu romanın genelde bilgi seviyesi kısıtll, edebiyat ve romana dair bilgisi sınırlı kişilerce eleştirildiğini söyleyebiliriz. Zaten eleştiriler de genellikle bir olguyla temellendirilmemektedir. Ağırlıklı olarak "Yazar saçmalamış." görüşü hakimdir ve devamı gelmemektedir. Fakat geçmişte büyük çoğunluk tarafından değer görmeyen, "trivial" olarak değerlendirilen postmodern romanın günümüzde belirli bir okur kitlesi tarafından değer görüyor olması sevindiricidir. Bu, hala "kaliteli" bir okur kitlesinin olduğunu göstermektedir.

Posmodern romanın kolektif bir biçimde 1970'li yıllarda ortaya çıktığını 80'li yıllarda ise ağırlık kazandığını söyleyebiliriz. Bir kurama oturtulmasının hemen ardından roman örnekleri ortaya çıkmaya başlamıştır. Elbette daha öncesine dair örnekler bulmak mümkündür. Fakat bu örneklerde kolektif bir üretim söz konusu değildir. Daha çok sadece kavrama başvurma veya tek tük örnekler ya da kısıtlı postmodern öge barındırma durumları söz konusudur. Postmodern romana dair seri üretimden ancak 1980'li hatta 9o’lı yıllarda bahsedilebilir.

Postmodern roman yazmanın güçlüğü, bu ögeleri metne hasretmenin güçlüğü açıtır. O yüzden postmodernist yazarlar gerçek romancılardır. Bu ögeleri metinde başarıyla taşıyan romanlar da bir dehanın ürünüdür. Bu romancıların dünyadaki temsilcileri birkaç tanesi Italo Calvino, Umberto Eco, Paul Auster, Orhan Pamuk, Kazuo Ishiguro olarak sıralanabilir. Önemli eserlere Bir Kış Gecesi Eğer bir Yolcu (1979), Gülün Adı (1980), New York Üçlemesi (1985-1986), Foucault Sarkacı (1988), Kara Kitap (1990), Kraliçe Loana'nın Gizemli Alevi (2004), Beni Asla Bırakma (2005), Masumiyet Müzesi (2009), 4321 (2017) örnek olarak gösterilebilir. Türk edebiyatında ise postmodern roman Oğuz Atay, Hasan Ali Toptaş, Süreyyya Evren üzerinden ağırlıklı olarak temsil edilmektedir. Bazı önemli eserler 
Tehlikeli Oyunlar (1973), Postmodern Bir Kız Sevdim (1993), Bin Hüzünlü Haz (1999) olarak sıralanabilir.

\section{Romanda postmodern ögeler}

Postmodern roman romantik, realist, natüralist roman gibi görülmemelidir. Postmodernizmin edebiyatta yer bulması bir dönemsel anlam taşımamaktadır. Zira böyle olsaydı 1960'larden sonra yazılan her roman postmodern roman olurdu. Postmodern kültürde yazılan her roman postmodern olduğu düşüncesine kapılmamak gerekir. Postmodern roman daha çok bir türü ifade etmektedir. Yani tarihsel roman, macera romanı, oluşum romanı, korku romanı gibi postmodern roman da bir türdür. Fakat postmodern romanın bu noktadaki özelliği bu türleri de isterse barındırabileceğidir. Somutlaştırmak gerekirse, postmodern bir roman aynı zamanda macera romanı olabilir. Türlerarasılık bağlamında birden fazla türe dahil edilebilir. Aynı anda hem korku romanı hem gelişim romanı hem de sosyal roman olabilir. Türlerarasılık postmodernin tipik bir özelliğidir. Postmodern romanın postmodern roman olarak nitelendirilebilmesi için türlerarasılık dışında belirli ögeleri de taşıması gerekir. Bu ögeler üstkurmaca ve metinlerarasılık olarak iki ana başlık altında incelenebilir.

Üskurmaca (Alm.: Metafiktion, İng.: Metafiction) kabaca gerçek ile kurmaca arasındaki çizginin hem vurgulanması hem de silikleştirilmesi olarak tanımlanabilir. Üstkurmacayı gerçekleştirmenin yolu gerçek ile kurmacayı birbirine harmanlama, kurmaca içerisinde kurmaca kurgulama, okura yönelme, eserin yazılışını eserde anlatma yöntemlerinden geçer. 20. yüzyıl insanının değişen gerçeklik algısı postmodern romanda üstkurmaca düzlemde yansitılır. Neyin gerçek neyin kurmaca olduğu belirsizdir. Normal şartlarda somut dünya bizim için gerçektir, roman ise kurmacadır. İtalyan postmodernist romancı Umberto Eco'nun "kurmaca anlaşması” (Eco, 2019: 101-102) olarak nitelendirdiği anlaşmaya göre ise okur romanı eline aldığında anlatı onun için gerçek konumundadır. Somut dünya o esnada askıya alınır. Okur "inançsızh̆̆ anlatıda geçenler okur için gerçektir. Fakat gerçek olarak algılansa bile roman, edebiyatın kurmaca ana türünün bir ürünüdür ve içerisinde geçenler kurmacadır. Bu kurmacada yazar, somut dünyadan bir kişi olarak romana dahil olur. Somut dünyadan kendisi dışında kişileri de metne dahil eder. Kimi noktalarda okurla veya okur adına konuşur. Bazı yerlerde eserin yazılış hikayesini eserde konu eder. Hatta bunu bir adım öteye taşıyıp gelecekte esere yöneltilecek muhtemel eleştirilere eser içerisinde peşinen cevap verir. Diğer bir yandan eserin içerisinde karakterine metinler yazdırır. Anlatı içerisinde içanlatı, kurmaca içerisinde kurmaca kurar. Bütün bunları bir oyun düzleminde gerçekleştirir. Okur, neyin gerçek neyin kurmaca olduğunu ayırt etmekte zorlanır. Bunların sonucunda "kurmaca gerçek" ve "gerçek kurmaca" kavramları doğar. Bunların sonucunda bir tanım önermek gerekirse, Ecevit’in tanımı esas alınabilir:

"Üstkurmaca için postmodern edebiyatın ana kurgu ögesidir de diyebiliriz. Bu eğilim genel bağlamda, yazma ediminin kurmaca metnin içinde kurgulanması demektir. Bu, yazarın metnini nasıl yazdığını o metnin içinde anlatması, yazma sorunlarını metninin ana konusu durumuna getirmesi ve kimi kez de okurunu metnin içine sokarak, romanını nasıl oluşturduğunu onunla paylaşması anlamına gelir; edebiyatın kendini anlatması, kurgulamasıdır üstkurmaca, kurmacanın kurmacasıdır." (Ecevit, 1996: 110).

Üstkurmacayı öte yandan sanat ile gündelik yaşam arasındaki sınırın silikleşmesi, seçkin kültür ile popüler kültür arasındaki hiyerarşik ayrımın çöküşü, derlemeciliğin yükselişi, kodların karışarak kırma bir hal alması ve oyunsuluk olarak değerlendirmek mümkündür (Sarup, 2019: 188). Trivial, karnaval bir havada ilerleyen ve gelişen postmodern roman için "ciddiyetsiz, değersiz, eğlencelik" yakıştırmaları yapılabilir. Fakat bu yakıştırmalar postmodern romanın zaten teknikleridir. Romancı 
bunları bilerek isteyerek, birer teknik olarak ele alır ve eserine işler. Dolayısıyla postmodern romanı değersizleştirmek ve eğlencelik edebiyatın bir ürünü haline getirmek, bu romanın ancak anlaşılmadığını gösterir. Postmodern roman bilinçli olarak bu teknikleri kullanır ve çok net bir şekilde yüksek edebiyat (Alm.: Hochliteratur) ürünüdür. Basit bir yazarın üstkurmacaya dair teknikleri gerçekleştiremeyeceği açıktır. Yapmaya çalışsa bile, ki yapmaya çalışan yazarlar vardır, yapaylık hemen göze batacaktır ve batmaktadır da.

Metinlerarasılık (Alm.: Intertextualität, İng.: Intertextuality) postmodern romanın diğer bir ana başlı̆̆ıdır. Metinlerarasılık, içerisinde referans (alıntı, gizli alıntı, gönderme), pastiş, parodi, ironi, kolaj tekniklerini barındırır. Metinlerarasılık genel anlamda bir metnin en az başka bir metinle olan ilişkisi olarak tanımlanabilir. Bu ilişkiyi gerçekleştirmenin alt teknikleri vardır. Bu tekniklerin bütünü metinlerarasılığı var eder. Diğer bir ifadeyle bu teknikler uygulanarak metinlerarası ilişkiler kurulmuş olur. Edebiyat bilimci Kubilay Aktulum metinlerarasılığı şöyle tanımlar:

\begin{abstract}
“Kristeva’nın ortaya attığı ve 1960’lı yılların sonlarından başlayarak her yazınsal çözümlemenin artık zorunlu bir aşaması olarak görülen metinlerarası, kabaca iki ya da daha çok metin arasında bir alışveriş, bir tür konuşma ya da söyleşim biçimi olarak anlaşılmalıdır.

$\cdots$

Bir yazar başka bir yazarın metninden parçaları kendi metninin bağlamında kaynaştırarak yenidenyazar. Her söylemin başka bir söylemi yinelediğini, her yazınsal metnin daha önce yazılmış olan metinlerden ayrı olarak yazılamayacağını, her metnin açık ya da kapalı bir biçimde önceki metinlerden, yazınsal gelenekten izler taşıdığını savunan yeni eleştiri yanlıları onun 'alıntısal' özelliğini göstermeye uğraşırlar. Hepsi de metnin bir alıntılar toplamı olduğunu, her metnin eski metinlerden aldığı parçaları yeni bir bütün içerisinde bir araya getirdiğini ileri sürerler. Metinlerarasında, her metnin kendinden önce yazılmış öteki metinlerin alanında yer aldığı, hiçbir metnin eski metinlerden tümüyle bağımsız olamayacağı düşüncesi öne çıkar." (Aktulum, 2000: 1718).
\end{abstract}

Kutsal metinlerin "Önce söz vardı!” anlayışını metinlerarasıllı̆ın merkezine oturtabiliriz. Hiçbir metin bu anlayışa göre özgün değildir. Bir metin, o şekilde veya bu şekilde daha önceden yazılmış bir metnin genel veya özel parodisidir. Böyle bir durum ilk bakışta söz konusu değilse, belirli kısımlar kolajlanmıştır ya da en azından herhangi bir metne dair göndermeler vardır. "Söylenmemiş olan ne kaldı ki?” düşüncesi hakimdir. Mühim olan söyleneni yapıbozuma tabi tutmak ve onu yeniden ele almaktır. Her şeye karşı olduğu gibi ortaya koyulmuş metinlere karşı da kuşku söz konusudur. Dolayısıyla metinlerin de yeniden ele alınması gerekir. Öte yandan postmodernist Fransız filozof Jacques Derrida'nın “There is nothing outside of the text. (T.: Metnin dişında kalan hiçbir şey yoktur.)" (Derrida, 1997: 158) ifadesini dünyanın bir metin olduğu ve hiçbir varlığın bu metnin dışında olmadığı şeklinde yorumlarsak, bu metnin içerisindeki hangi varlığın bir başka varlıkla ilişkisinin olmadığını iddia edebiliriz? Dolayısıyla var olan her nesne bir başka nesneyle ilişki içerisindedir. Metinlerarasılığın felsefesinin bu sayılan noktalarda yattığını söyleyebiliriz.

Metinlerarasılığın referans tekniğine başvurması çeşitli alt teknikler ile mümkündür. Alıntı, gizli alıntı, gönderme vs. gibi alt teknikler üzerinden metinlerarası ilişkiler kurulabilir. Akademik bir metinden yola çıkarak anlatmaya çalışırsak, bu makaleyi örnek olarak ele alabiliriz. Romancı eğer kaynă̆ını bildirerek bir kişi veya metne ait ifadeyi metnine yapıştırıyorsa bu alıntıdır. Alıntı tekniğinde, alıntılanan yer genel itibariyle italik şekilde veya tırnak içerisinde yer bulur. Türk romanında birkaç yayınevi dışında buna rastlamak pek alışılmış bir durum değildir. Fakat bu atlanmaması gereken önemli bir durumdur. Romancı orayı amaçsızca italik veya tırnak içerisinde yazmamıştır. Buna pek özen gösterilmese de bu, söz konusu ifadenin başka bir kişiye veya harici bir metne ait olduğunun göstergesidir. Diğer bir teknik ise gizli alıntıdır. Gizli alıntıda hırsızlık, aşırma söz konusudur. Bu 
teknikte romancı başka bir kişi veya metne ait ifade veya düşünceyi alır fakat kaynak belirtmez, genellikle kendisine aitmiş gibi sunar. Yalnız bunun gizli bir alıntı olduğunun da sinyalini romanda buluruz. Yani romancı bunu yaratıcılık yoksunluğundan dolayı değil, bilerek ve isteyerek bir tekniği gerçekleştirmek adına yapar. Göndermede ise ikisinin arasında bir durum söz konusudur. Bu teknikte romancı kişinin veya eserin adını anar, fakat ifadeyi direkt olarak aktarmaz. Sadece atıfta bulunmuş olur. Okuru söz konusu metne yönlendirir. Dolayısıyla okurda merak duygusu canlanır ve bu okur adı geçen metne yönelir. Romancı bu metni okumuş, bu metne kafa yormuşsa aynılarını okurdan da bekler. Dolayısıyla şöyle özetleyebiliriz: Kişi veya metni kaynak belirterek doğrudan alıntılama alıntı, kaynak belirtmeden alıntılama gizli alıntı, kaynak belirtip kişi veya metnin ifadesini doğrudan aktarmama gönderme olarak tanımlanabilir. Akademik metinlerde de durum böyledir. Kişinin ifade ve düşünceleri tırnak içerisinde, italik olarak veriyorsa bu doğrudan alıntıdır. Kişinin ifade ve düşünceleri alınıp kişiye dair kaynak bildirilmiyorsa bu gizli alıntı, aşırma, hırsızlık, intihaldir. Kişinin ifade ve düşüncelerine dolaylı bir gönderme söz konusuysa bu atıftır. Dolayısıyla referans başlı̆̆ı altında toplayabileceğimiz üç temel teknik bunlardan oluşmaktadır. Bunlar dişında da alt tekniklerden bahsedilebilir, fakat önemli görülebilecekler bu üç tekniktir.

Pastiş üzerine farklı tezler bulmak mümkündür. Tanımlanması güç bir tekniktir. Pastiş anlamını edebiyat bilimci Gürsel Aytaç şöyle açıklar: "(İt. pasticco'dan Fransızcaya geçmiş bir terim): Ash karmakarışık, çorba anlamında ya orïinallikten uzak ya da özellikle bir kişi ya da dönem üslubunun taklidi." (Aytaç, 2016: 319). Aktulum'un pastiş tanımı ise şöyledir: "Öykünme, bir yazarın dil ve anlatım özellikleri, sözleri taklit edilerek gerçekleşir. Bir yazar bir başka yazarın biçemini kendi biçemiymiş gibi benimseyerek, okurun üzerinde oluşturmak istediği etkiye göre kendi metnine sokarak ya da özgün metnin içeriğini kendi metnine uyarlayarak yeni bir metin ortaya çıkartr." (Aktulum, 2000: 133). Tanımlar ışı̆ında yorum üretmek gerekirse, pastiş bir yazarın başka bir yazarın anlatı üslubunu alması, taklit etmesi olarak tanımlanabilir. Fakat Aktulum "Ancak öykünme yalnızca biçemsel bir taklitle sinurlanmamall; bir metnin özgün içeriği, izleği de taklit edilebilir.” (Aktulum, 2000: 133) der. Aktulum'un öykünme (pastiş) tanımını eklediğimiz zaman iş daha da karmaşık bir hal almaktadır. Elbette Kubilay Aktulum bu alandaki otoritelerden biridir. Onun ortaya koyduğu bir tezi çürütmek güçtür. Fakat yanlışlama anlamında değil, ama katılmama anlamında bir ifade ortaya koymak gerekirse, ben içeriğe dair taklidi parodiye dayandırıyorum. Biçimsel taklit, şahsi kanaatime göre pastiş tekniğini ilgilendirmektedir.

Parodi daha önce yazılmış olan bir metnin bir kısmının veya tamamının yeniden ele alınması olarak tanımlanabilir. Parodide bir tarafta kaynak metin bir tarafta da hedef metin söz konusudur. Kaynak metin özel veya genel açıdan ele alınır ve ortaya hedef metin çıkar. Kuram tarihçisi Margaret A. Rose bir dizi tanımı tartıştıktan sonra kapsayıcı bir tanım önerir: “... parodi genel itibariyle önceden şekillendirilmiş dilsel veya sanatsal malzemenin komik biçimde yeniden işlevlendirilmesi olarak tanımlanabilir." (Rose, 2016: 78). Rose'un tanımı elbette geçerli ve kapsayıcı bir tanımdır. Fakat parodilerin her zaman komik olduğunu söyleyemeyiz. Ciddi ve komiklikten uzak parodiler de bulmak mümkündür. Aktulum da parodinin gülünç, alaycı tarafını kabul eder (Aktulum, 200o: 117) fakat şunu ekler: "Bunu yaparken de yazarlar soylu, ciddi bir metni, çoğunlukla stradan başka bir metne, ya da soylu bir metnin biçemini -çoğunlukla da destanın biçemini- hiçbir kahramanlık olayı anlatmayan stradan bir konuya uyarlarlar." (Aktulum, 2000: 117-118). Bu defa da biçimin söz konusu olduğunu görüyoruz. Oysaki biçim pastiş tekniğini ilgilendiriyordu. Bunların arasındaki ince çizgilerin hepsini "metinlerarasılık" üst başlığı zaten kapsar, fakat yine de ayırmak gerekirse şu söylenebilir: Biçim pastiş tekniği ile, içerik ise parodi tekniği ile taklit edilir. 
İroni tekniği postmodern romanın vazgeçilmez tekniklerinden biridir. Romancının, dil oyunları yaparken en çok başvurduğu teknik ironi tekniğidir. İroni yapısalcıların gösteren-gösterilen arasındaki ilişkisini adeta rafa kaldırır. Normal şartlarda gösteren "bilgisayar" sözcüğü ise zihnimde hemen bir bilgisayar nesnesi canlanır. Gösteren ile gösterilen arasındaki bağlantı nedensiz olsa da bu böyledir. "Masa" sözcüğüyle zihnimde bilgisayar resmi canlanmıyorsa, "bilgisayar" sözcüğü ile programlama yeteneğine sahip bir cihaz arasında bağlantı somut bir şekilde vardır. İronide bu bağlantı farklı bir boyut kazanır. Kişi dediğinin aksine bir durumu kasteder. Karnesi kötü gelmiş bir çocuk için annesi "Baksanıza ne kadar da başarılı bir oğlum var!" dediğinde kastettiği, söylemek istediği şey açıktır. İroni tekniğiyle oğlunun başarısızlığından dem vurur. Öte yandan başka metinlere eleştirel, alaycı yaklaşımda yine ironi üzerinden gerçekleşir. Postmodernist romancının modern hayata dair düşüncelerinde anahtarı yine ironidir. Tarihe yaklaşımı, tarihle hesaplaşması da yine ironik düzlemde gerçekleşir. Kısacası, ironinin postmodern romanda en sık rastlanılan metinlerarası teknik olduğunu söyleyebiliriz.

Kolajın tanımlamak, varsa montaj ile ayrımını ortaya koymak güçtür. Kolaj dışarıdan bir nesneyi metne yapıştırmak, dahil etmektir. Bu bir resim olabileceği gibi, mektup, gazete, anket gibi metin dışı herhangi bir şey olabilir. Romanda kolaj ile montajı ayrı teknikler olarak ele alan çalışmalar (bk.: Eliuz, 2016: 143, 145) olsa da kolaj Dadaistlerden beridir montajın yerine kullanıldığını değerlendiriyorum. Bu yüzden olacak ki ne Aktulum ne de diğer bir edebiyat bilimci Bedia Koçakoğlu "montaj" gibi bir tekniğe çalışmalarında değinmemişlerdir (bk.: Aktulum, 2000; Koçakoğlu, 2012). Dolayısıyla metinlerarasılık bağlamında bir "montaj" tekniğinden bahsetmek doğru bir tez olmayacaktır. Şunu da eklemek gerekir: Filmdeki gibi romanın montajı, kurgulanması yani birleştirilmesi ayrı bir şeydir. Bu anlamdaki montajı kolaj ile karıştırmamak gerekir. Kullanılacaksa da birbirlerinden ayırmak güçtür. Aytaç kolajı şöyle tanımlar: "(Alm. Collage, Fr. yapıştırma) Resim sanatından gelme bu terim, hazır ünitelerin biraraya getirilmesiyle yeni bir kompozisyon oluşturma demektir. Burada her bir unsur, sembol niteliği taşıyan bir bütün içinde organik bir yapı ögesi kazanır.” (Aytaç, 2016: 312). Koçakoğlu'na göre ise kolaj şu demektir: “... metinlerarası bir yöntem olan kolaj, metin dışı unsurları esere sokmak için kullanılan bir yoldur. Bu şekilde dişarıdan alntılanan bu unsurlar, yeni bir bağlamda yinelenerek, yeniden yazılarak metinlerarasılğın sınırları zorlanmış olur.” (Koçakoğlu, 2012: 106). Dolayısıyla kolajda bir bütünlük oluşturacak şekilde metne harici bir nesnenin yapıştırılması demektir. Metin bir yanda bir bütün olarak görünürken, diğer yanda kopukluk hissi verir.

Montaj (kurgu) ögesi postmodern romana parçalanmışlık hissi vermek için kullanılır. Her şeyin darmadağın olduğu bir dünyada düzenden bahsetmek olağan değildir. Bu yüzden romanda kopuk parçalar montajlanır ve parçalanmışlık hissi verilir. Postmodern romanda zamansal akış çoğunlukla akroniktir. Analepsis ve prolepsis teknikleriyle bir geri dönülür, bir ileri gidilir. Dolayısıyla okurun uyanık olması gerekir. Hatta sarmal yapıda kurgulanan romanlara dahi rastlanır. Söz gelimi birinci bölümden sonra kırkıncı bölüm okunmalı, sonra ikinci ile otuz dokuz ve bu şekilde birleşinceye kadar. Bütün bunlar hem sağlam bir kurgu oluşturmak hem de parçalanmışlık, kopukluk hislerini aktarmak için bilinçli olarak başvurulan tekniklerdir.

Son olarak, üstkurmaca ve metinlerarasılığın yanı sıra postmodern roman, bazı olguları malzeme olarak kullanır. Modernizme ve modern hayata bakışı pek olumlu olmayan postmodern romanda modern dünya ve modern hayat eleştirisi yapılır. Modern dünya uygarlığın kazanımı olarak değil uygarlığın yıkıcılığının bir sonucu olarak görülür. Romancı her ne kadar mesaj verme kaygısı gütmese de inceden inceye değinir bu meselelere. Modern hayatın birey olamamış kişisi ruh hastalıklarıyla dolu 
bir doğada yaşamaktadır. Kaosun, zıtlıkların, paradoksların, anlamsızlıkların hakim olduğu bir dünya söz konusudur. Dolayısıyla postmodernist romancı için bu sağlam bir malzemedir. Aydınlanma, Marksizm, modernizm gibi anlatıların 20. yüzyıl dünyasının ve insanının geldiği noktanın suçluları konumuna getirilir. Aynı zaman da tarihi de anlatı malzemesi yapar postmodernist romancı. Tarihe bir tarihçi perspektifiyle değil, onunla hesaplaşan bir kişi olarak yaklaşır. Tarihle hesaplaşırken tarihi ders alınacak bir olgu olarak sunar. Fakat yine de amacı ders vermek, mesaj aktarmak değildir. Postmodernist romancı, büyük çaba harcadığı ürününü dehasını konuşturarak ortaya koyar, fakat sözü okura birakır.

\section{Sonuç}

Postmodernizmin üst-anlatılara karşı kuşkucu ve anarşist yapısının yanı sıra şizofreni ve paranoya barından tavrı nispeten postmodern romana da yansımıştır. Modern dünyanın, modern hayatın parçalanmışlık, kopukluk duyguları postmodern romanda yer bulmaktadır.

Üstkurmaca bağlamında gerçek ile kurmaca arasındaki çizginin bir yandan belirginleştirilmesi, diğer yandan da silikleştirilmesi, kurmaca içinde kurmaca kurma, okura yönelme ve eserin yazılma hikayesini romandaki anlatıya yerleştirme gibi olgulara oyun düzleminde başvurulmaktadır. Diğer tarafta, metinlerarasılık bağlamında referans, pastiş, parodi, ironi ve kolaj teknikleri kullanılmaktadır. Referans alıntı, gizli alıntı, gönderme alt türlerine başvurulmasıyla; pastiş ve parodi romancının tematik ve teknik taklitçiliği üzerinden; ironi dil oyunlarıyla; kolay metin dışı ögelerin metnin içerisine dahil edilmesiyle gerçekleştirilmektedir.

Üstkurmaca ve metinlerarasıllğın yanı sıra tematik materyal olarak modern dünya/hayat eleştirisi yapılmaktadır. Romancı tarihle hesaplaşmaktadır. Paradoksal bir anlatı hakimdir. Romancı kaosu sunmakta, fakat yorum yapmamaktadır.

Postmodernizm çeşitli boyutları üzerine yazılan elbette oldukça fazla çalışma vardır. Fakat bu çalışmaların gerek sadece belirli bir açıya yönelmeleri gerekse çoktan yanlışlanmış (çürütülmüş) teorileri ele almaları, bu çalışmaları anlaşılması güç kılmaktadır. Öte yandan postmodern romanı bir makaleye sığdırmanın güçlüğü de ortadadır. Dolayısıyla bu çalışma hem kısa fakat özet niteliğinde olması hem de erişime açık olacak biçimde basit bir el kaynağı olması amacıyla birincil kaynaklar gözetilerek hazırlanmıştır.

\section{Kaynakça}

Aytaç, G. (2016). Genel Edebiyat Bilimi. Ankara: Doğu Batı.

Best, S. \& Kellner, D. (2016). Postmodern Teori. İstanbul: Ayrıntı.

Derrida, J. (1997). Of Grammatology. London: Johns Hopkins.

Eco, U. (2019). Anlatı Ormanlarmda Altı Gezinti. İstanbul: Can.

Ecevit, Y. (1996). Orhan Pamuk’u Okumak. İstanbul Gerçek.

Ecevit, Y. (2016). Türk Romanında Postmodernist Açllımlar. İstanbul: İletişim.

Eliuz, Ü. (2016). Oyunda Oyun Postmodern Roman. İstanbul: Kesit.

Hassan, I. (2019). Orpheus'un Parçalanışı: Postmodern Bir Edebiyata Doğru. Ankara: Hece.

Koçakoğlu, B. (2012). Anlamsızhğın Anlamı Postmodernizm. Ankara: Hece.

Lyotard, J-F. (2014). Postmodern Durum. Ankara: BilgeSu. 
390 / RumeliDE Journal of Language and Literature Studies 2020.19 (June)

Postmodern elements in the novel / E. B. Güven (pp. 378-386)

Rose, M. A. (2016). Parodi: Antik, Modern ve Postmodern, Ankara: Hece.

Sarup, M. (2019). Post-Yapısalcllk ve Postmodernizm. Ankara: Pharmakon.

Stevick, P. (2017). Roman Teorisi. Ankara: Akçă̆. 